\title{
CITRA PEREMPUAN DALAM IKLAN KECAP DI MEDIA MASSA
}

\author{
YULI SUSIYANAH \\ Ma'had Uin Walisongo Semarang, Mahasiswa Progam Pascasarjana UIN Walisongo \\ Semarang \\ Email: Yuli.susiyanah@gmail.com
}

\begin{abstract}
7 his article examines the image of women in soy sauce advertisements in the mass media. In general, the image of them in the mass media is depicted by stereotypes and patriarchal cultures inherent in them. They are generally described as agents of domestic roles and sex objects, who must be discriminated and subordinated. The theory used in this paper is gender relationship and mass media with qualitative content analysis. The theory is applied to analyze the positions between men and women in order to realize gender equality. Using qualitative content analysis, ABC soy sauce ads "true husbands want to cook" shows that there is a reconstruction concept of the relationship between men and women from a stereotypical and patriarchal culture to be a culture of gender equality. In this advertisement, the domestic job that is identified with the duty and responsibility of woman being able to be reconstructed into a role that can be performed by all people including men. It can shape public opinion about the image of women who must not be discriminated in the mass media.
\end{abstract}

\section{Keywords: Women's Image, Gender Realtionship, Mass Media, Advetising}

\begin{abstract}
ABSTRAK
A rikel ini mengkaji citra perempuan dalam iklan kecap pada media massa. Secara 1 umum, citra perempuan pada media massa digambarkan dengan stereotif dan budaya 1 patriarkhi yang melekat pada perempuan, seperti perempuan sebagai agen peran domestik dan objek seks, yang didiskriminasi, dimarjinalisasi, dan disubordinasi. Paper ini menggunakan teori gender relationship dalam media massa dengan analisis kualitatif isi. Teori gender relationship digunakan untuk menganalisis peran antara laki-laki dan perempuan guna mewujudkan kesetaraan gender. Dengan menggunakan analisis kualitatif isi, Iklan kecap ABC "suami sejati mau masak" menunjukkan bahwa terdapat rekonstruksi konsep hubungan antara laki-laki dan perempuan yang selama ini berkembang di masyarakat dari budaya stereotif dan patriarkhi menjadi konsep kesetaraan gender. Dalam iklan ini, peran domestik yang diidentikkan dengan tugas dan tanggungjawab perempuan mampu direkonstruksi menjadi sebuah peran yang bisa dilakukan oleh semua orang tidak terkecuali laki-laki. Hal ini dapat membentuk opini publik mengenai citra perempuan yang tidak harus didiskrimnasi di media massa.
\end{abstract}

\section{Kata kunci: Citra Perempuan, Gender Relationship, Media Massa, Iklan}




\section{PENDAHULUAN}

Media massa, sebagai sumber informasi, telah menjadi bagian penting dalam kehidupan di era teknologi. Manusia hidup bersama dengan media dan dalam prosesnya juga dipengaruhi oleh media (dipengaruhi oleh berbagai hal dan informasi yang terdapat dalam Media). Media bahkan sanggup mengubah serta mengarahkan situasi sosial dari masyarakat penggunanya baik dalam pola fikir, stigma, stereotip maupun pandangan mengenai sesuatu hal atau informasi yang di dapat dari media. Hal ini juga terjadi dalam kasus perempuan yang digambarkan oleh media (Nahayi, www.academia.edu.ac.id).

Perempuan dalam media selalu ditampilkan dalam berbagai bentuk, pencitraan, dan budaya patriakhisme. Ia tak jarang menjadi konsumsi media atau mungkin media dimanfaatkan untuk membangun citra diri mereka. Citra perempuan di media massa sendiri masih bersifat klise. Artinya citra perempuan di media massa cenderung bersifat stereotip dan juga diskriminatif (Halim, t.t: 15). Dalam pandangan masyarakat misalnya, perempuan dianggap sebagai objek seks yang fungsi utamanya untuk melayani pria.

Oleh karena itu, munculah persepsi bahwa perempuan harus tampil dengan menonjolkan daya tarik seksual, harus bersedia mengalami pelecehan seksual, dan harus memaklumi perilaku agresif laki-laki. Semua citra itu berada di dalam pemberitaan media massa seperti iklan di televisi maupun dalam sinetron-sinetron (Hariyanto, 2009: 2).

Begitu banyak iklan di televisi yang menggunakan perempuan sebagai modelnya, tentu menjadi sebuah keunikan tersendiri. Munculnya perempuan pada berbagai iklan di televisi, seperti sabun cuci, detergen, pegawai pakaian, bumbu masak, larutan pembersih lantai, dan masih banyak lagi merupakan contoh kecil bagaimana perempuan dicitrakan dalam posisi domestik. Bila dipandang dengan perspektif komunikasi di mana segala sesuatu memiliki pesan maka iklan televisipun memiliki pesan yang hendak di sampaikan kepada halayak. Beragam iklan yang menggunakan perempuan sebagai modelnya menyimpan berbagai pesan yang dapat diekstrak untuk mengetahui bagaimana sebuah iklan mampu mempengaruhi citra perempuan dalam masyarakat (Pardede, 2016: 2-3).

Pandangan di atas menujukkan adanya stereotip terhadap perempuan. Hal itu ditampilkan dalam kedomestikan perempuan sebagai pengurus urusan domestik dalam keluarga serta peran seseorang perempuan sebagai objek seks. Dalam penelitian yang dilakukan oleh Yanti Dwi Astuti mengenai "Media dan Gender (Studi Deskriptif Representasi Stereotipe Perempuan dalam Iklandi Televisi Swasta)", dinyatakan bahwa kekuatan iklan dalam menghasilkan produk pencitraan telah ikut andil dalam menyuburkan stereotipe yang selama ini dilekatkan pada perempuan. Simbol-simbol sosial yang selama ini dilekatkan pada perempuan kemudian diolah lebih jauh secara kreatif oleh para pembuat iklan untuk lebih mendekatkan produk yang akan ditawarkan dengan kemauan konsumen. Produk-produk yang ditawarkan berupa Sabun, Detergen, Handbody, Suplemen obat kuat, makanan dan lainnya selalu menggunakan ikon wanita sebagai alat jual yang cukup signifikan (2016: 25).

\section{Islamic Communication Journal Volume 4, Nomor 1, Januari-Juni 2019


Hal senada juga disampaikan oleh Burhan Bungin dalam bukunya yang berjudul Sosiologi Komunikasi (dalam Halim, t.t: 16) yang menyatakan, bahwa perempuan ditampilkan untuk mengeksploitasi keindahan perempuan, dengan mengembangkan stereotip perempuan, seperti perempuan harus tampil menawan, pandai mengurus rumah tangga, pandai memasak, terampil, dapat menyenangkan suami, cerdas dan dapat dibawa dalam berbagai kegiatan. Berbagai stereotip ini menjadi ide dan citra sekaligus menjadi sumber perberkembangan stereotif perempuan di berbagai media dan iklan. Padahal di sisi yang lain perempuan dianggap sebagai sumber pengetahuan dan moral keluarga bukan hanya sebagai objek seksual kaum laki-laki dan pemeran domestiksitas. Hal ini tentu ada ketimpangan yang menonjol antara peran laki-laki dan perempuan, di mana perempuan ditampilkan sebagai objek seks.

Selain itu, dalam media, perempuan juga tidak lepas dari adanya pandangan diskriminatif. Dalam penelitian Mustika (2016: 41) yang berjudul "Diskriminasi terhadap Beberapa Perempuan dalam Persepektif Feminisme Multikultural: Kajian Terhadap Novel Scappa Per Amore Karya Dini Fitria" disebutkan bahwa beberapa perempuan dalam novel SPA didiskriminasi bukan hanya karena persoalan mereka adalah perempuan, tetapi juga dipengaruhi oleh faktor usia, agama, suku, dan status anak. Hal ini sejalan dengan pandangan feminisme multikultural, bahwa semua perempuan tidak dikonstruksi secara setara. Bergantung kepada ras dan kelas, dan juga kecenderungan seksual, usia, agama, pencapaian pendidikan, pekerjaan, status perkawinan, kondisi kesehatan, dan sebagainya. Paham feminis multikultural yang menekankan aspek multikultur, sangat menjunjung tinggi keberagaman. Semestinya tidak ada diskriminasi terhadap perempuan yang berusia berapapun, beragama apapun, bersuku apapun, dan berstatus apapun. Semuanya harus diperlakukan secara setara dan harus mendapatkan penghargaan yang sama.

Penelitian Danik Fujiati (2016: 26) dengan judul "Seksualitas Perempuan dalam Budaya Patriarkhi," juga menyatakan bahwa kontribusi patriarki atas kontrol seksualitas perempuan menjadikan kaum perempuan mengalami kondisi di mana apapun yang menimpa tubuh perempuan (biologis), dikarenakan kesalahan perempuan sendiri. Lebih ironis lagi, dalam pandangan masyarakat yang patriarkhisme, diskriminasi terhadap perempuan atas domestiksitas tubuh perempuan menjadi hal yang dianggap wajar oleh masyarakat, bahkan negara.

Hal lain juga dingkap oleh catatan tahunan milik Komnas perempuan yang menerangkan bahwa terdapat 321.452 kasus kekerasan terhadap perempuan di Indonesia pada tahun 2015 (Pardede, 2016: 1) dan meningkat $74 \%$ dari tahun sebelumnya menjadi 348.446 kasus kekerasan perempuan di tahun 2017, setelah sebelumnya hanya mencapai angka 259.150 kasus di tahun 2016. Hal ini memperlihatkan bahwa perempuan masih berada dalam posisi yang lemah dalam masyarakat. Catatan tahunan ini menjelaskan bagaimana kasus kekerasan tersebut terjadi dalam berbagai aspek dalam masyarakat, dari ranah keluarga hingga negara (Catatan Komnas Perempuan 2018, 
dalam

Https://

www.komnasperempuan.go.id: 1).

Menanggapi berbagai persoalan kompleks terkait perempuan, di mana perempuan dicitrakan sebagai objek seks dan stereotip perempuan sebagai pemeran domestik, maka menjadi menarik bagi penulis untuk mengkaji "Citra perempuan dalam Iklan Kecap pada Media Massa. Ini menjadi penting mengingat beberapa iklan di televisi masih menggunakan stereotif dan marginalisasi yang melekat pada diri perempuan. Artikel ini juga merupakan sebuah pengembangan dari teori gender dengan menggunakan pendekatan peranan media massa, walaupun beberapa penelitian gender dan media telah banyak dilakukan, tetapi penelitian yang secara spesifik mengkaji citra perempuan dalam iklan pada media massa belum banyak dilakukan.

\section{METODE PENELITIAN}

Jenis penelitian ini adalah penelitian kualitatif dengan data yang dikumpulkan berupa data kualitatif yaitu data yang disajikan dalam bentuk kata verbal bukan angka (Muhajir, 1996: 196). Analisis yang digunakan adalah analisis isi (content) media. Dalam penelitian ini, peneliti akan membuat gambaran atau deskripsi mengenai suatu keadaan secara objektif, mengenai iklan kecap ABC "Suami Sejati mau masak." Objek kajian dalam penelitian ini adalah iklan Kecap ABC suami sejati mau masak dengan durasi waktu 45 detik.

Pengumpulan data pada penelitian ini diawali dengan membuat pernyataan terstruktur terkait isi dari iklan kecap ABC Suami Sejati Mau masak, yang dalam hal ini ialah dialog percakapan, baru kemudian dilakukan cheklist, dan setelah itu dilakukan analisis menggunakan metode analisis tekstular. Setelah data-data diperoleh secara tepat dan akurat, maka dilakukan analisis. Analisis data dalam penelitian ini menggunakan analisis isi dengan bantuan teori gender dan pendekatan media massa. Analisis ini digunakan untuk mengungkapkan citra perempuan yang tertuang dalam Iklan Kecap ABC Suami sejati mau masak sebagai upaya untuk mengetahui perbedaan peran yang dilakukan oleh laki-laki dan perempuan demi terwujudnya kesetaraan gender.

\section{PEMBAHASAN}

Konsep Gender, Gender Relationship, dan Kesetaraan Gender

Istilah "gender" pertama kali diperkenalkan oleh Robert Stoller, untuk memisahkan pencirian manusia yang didasarkan pada pendefinisiannya baik bersifat sosial budaya maupun pendifinisian yang berasal dari ciri-ciri fisik biologis (Rahayu, 2016: 95). Gender sendiri secara etimologi berasal dari kata gender (Inggris) yang berarti jenis kelamin (Wojowasito dan wasito W, 1980: 66). Pengertian ini lebih menekankan hubungan laki-laki dan perempuan secara anatomis. Sedangkan dalam Webster's New World Dictionary (Amin, 2012: 18), gender diartikan sebagai perbedaan yang tampak antara laki-laki dan perempuan dilihat dari segi nilai dan tingkah laku. Definisi ini lebih menekankan aspek kultural dibandingkan pemaknaan secara anatomis. Dalam Women's Studies Encyclopedia dijelaskan bahwa gender adalah suatu konsep kultural yang berupaya membuat pembedaan dalam peran, perilaku, mentalitas, dan karakter 
Yuli Susiyanah

emosional antara laki-laki dan perempuan yang berkembang dalam masyarakat (Kadarusman, 2005: 20).

Dari penggertian di atas, gender dapat diartikan sebagai suatu konsep kultural yang berupaya membuat perbedaan (difference) dalam hal peran, tingkah laku, mentalitas, dan karakteristik emosional antara laki-laki dan perempuan yang berkembang dalam masyarakat
(Purwaningsih, 2009: 65). Gender lebih ditekankan kepada hal-hal yang bersifat kultural yang dibentuk oleh suatu stigma dan proses sosial bukan pada kodrati walaupun gender ini tidak lepas dari identitas jenis kelamin (seks) yang merupakan salah satu ketentuan atau kodrat Tuhan (Mufidah Ch, dalam www. academia.edu.ac.id: 1). Adapun perbedaan seks dan gender yaitu sebagai berikut:

Tabel Perbedaan Seks dan Gender

\begin{tabular}{|l|l|l|l|}
\hline No & \multicolumn{1}{|c|}{ Karakteristik } & \multicolumn{1}{|c|}{ Seks } & \multicolumn{1}{|c|}{ Gender } \\
\hline 1. & Sumber Pembeda & Tuhan & Manusia (masyarakat) \\
\hline 2. & Visi, Misi & Kesetaraan & Kebiasaan \\
\hline 3. & Unsur pembeda & Biologis (alat Reproduki) & Kebudayaan (tingkah laku) \\
\hline 4. & Sifat & $\begin{array}{l}\text { Kodrat, tertentu, tidak dapat } \\
\text { dipertukarkan }\end{array}$ & $\begin{array}{l}\text { Harkat martabat dapat } \\
\text { dipertukarkan }\end{array}$ \\
\hline 5. & Dampak & $\begin{array}{l}\text { Terciptanya nilai-nilai } \\
\text { kesempurnaan, kenikmatan, } \\
\text { kedamaian, dan lain-lain } \\
\text { sehingga menguntungkan } \\
\text { kedua belah pihak. }\end{array}$ & $\begin{array}{l}\text { Terciptanya norma-norma atau } \\
\text { ketentuan tentang "pantas" atau } \\
\text { "tidak pantas" laki-laki pantas } \\
\text { menjadi pemimpin perempuan } \\
\text { pantas dipimpin dan lain-lain. } \\
\text { Sering merugikan salah satu } \\
\text { pihak yang biasanya perempuan } \\
\text { atau laki-laki. }\end{array}$ \\
\hline 6 & Keberlakuan & Sepanjang masa dimana saja. & $\begin{array}{l}\text { Dapat berubah. } \\
\text { and }\end{array}$ \\
\hline
\end{tabular}

Dari tabel di atas dapat dipahami bahwa yang menjadi kodrat perempuan dan laki-laki tidak dapat dipertukarkan secara biologis, sedangkan dalam posisi sosial semuanya dapat ditukarkan sesuai dan kebutuhan masyarakat (Ni'matusyifa, 2014:18-19).

Konsep gender dalam perkembangannya juga melahirkan (pembedaan sosial-budaya antara feminim dan maskulin), seperti istilah kesetaraan gender dan relasi gender. Kesetaraan gender (gender equality) merupakan konsep yang dikembangkan dengan mengacu pada dua instrumen internasional yang mendasar yaitu Deklarasi Universal Hak Asasi Manusia dan Konvensi Penghapusan Segala Bentuk Diskriminasi 
terhadap Perempuan (CEDAW). Deklarasi Universal Hak Asasi Manusia menyatakan bahwa semua manusia dilahirkan bebas dan sama. Artinya, deklarasi ini merujuk pada konvensi tentang penghapusan segala bentuk diskriminasi terhadap perempuan dengan adanya hak yang sama untuk"lakilakidan perempuan" dan "kesetaraan hak laki-laki dan perempuan." Dengan kata lain, konsep kesetaraan gender merujuk pada kesetaraan penuh untuk laki-laki dan perempuan dalam menikmati aktifitas sosial seperti hak-hak politik, ekonomi, sipil, sosial maupun budaya (Siscawati, 2015: 6).

Adapun relasi gender merupakan hubungan sosial yang didasarkan pada pertimbangan aspek kesadaran dan peranperan gender. Menurut Helen Tierney dalam Women'sStudies Encyclopedia, "gender relations are differences in theirroles, behaviors, and mental and emotional characteristics between women and men developed bythe community."Artinya relasi gender merupakan perbedaan dalam peran, perilaku, dan karakteristik mental dan emosional antara perempuan dan laki-laki yang dikembangkan oleh masyarakat. Relasi gender yang dimaksud bukanlah atribut tertentu yang melekat pada laki-laki maupun perempuan, seperti pria selalu eksklusif menjadi pemimpin atau seorang prajurit dan perempuan juga eksklusif bertugas menjaga dan mengasuh anak. Kenyataan seperti inilah yang berdampak pada kehidupan perempuan dan laki-laki, baik di ranah domestik rumah tangga maupun di ranah publik yaitu dunia kerja, dunia pendidikan. Dengan demikian relasi gender akan bervariasi berdasarkan waktu, tempat, budaya serta pengalaman hidup dan dapat berubah sesuai kondisi lingkungan sosial dan budaya yang memengaruhinya. (Hatifah, dalam http:// www.medianeliti.com: 1099-1100).

Perbedaan gender yang terkontruksi secara sosial dan budaya oleh masyarakat secara turun temurun menyebabkan banyaknya bentuk-bentuk ketidak-adilan gender dalam bidang sosial, politik, ekonomi maupun pendidikan. Hal ini tentu merugikan dan memojokkan salah satu pihak, baik laki-laki maupun perempuan (Ni'matusyifa, 2014: 20-23). Adapun bentuk ketidak-adilan gender meliputi:

1. Marginasisasli: merupakan proses peminggiran sengaja atau tidak sengaja terhadap jenis kelamin tertentu.

2. Strereotip: pelabelan atau penandaan kelompok tertentu.

3. Kekerasan, dan

4. Subordinasi adalah anggapan bahwa perempuan tidak penting dalam megambil keputusan (Ramli, 2012: 147-148).

Analisis gender ini digunakan pada penelitian untuk mengetahui bagaimana pola hubungan gender dalam masyarakat yang merujuk pada pelbagai cara yang digunakan untuk memahami hubungan di antara laki-laki dan wanita, akses mereka terhadap sumber-sumber aktivi-aktivi mereka dan kekangan mereka terhadap satu sama lain. Analisis gender juga memperlihatkan berbagai peranan wanita dan laki-laki dalam struktur ekonomi, undang-undang dan politik demi terwujudnya kesetaraan gender. Dengan analisis gender ini diharapkan kesenjangan gender dapat teridentifikasi dan dianalisis secara tepat sehingga dapat ditemukan faktor-faktor penyebabnya serta langkahlangkah pemecahan masalahnya demi

\section{Islamic Communication Journal Volume 4, Nomor 1, Januari-Juni 2019


Yuli Susiyanah

terwujudnya kesetaraan gender

(Puspitawati, 2012: 10)

Dengan demikian, kesetaran gender dapat terwujud dengan ditandai tidak adanya diskriminasi antara perempuan dan laki-laki, mereka memiliki akses dan kesempatan berpartisipasi (memiliki peluang atau kesempatan untuk menggunakan sumber daya dan memiliki wewenang untuk mengambil keputusan terhadap cara penggunaan dan hasil sumber daya tersebut), serta kontrol (memiliki kewenangan penuh untuk mengambil keputusan atas penggunaan dan hasil sumber daya) sehingga memperoleh manfaat yang sama.

\section{Media Massa}

Media adalah bentuk jamak dari medium yang berati tengah atau perantara. Adapun massa berasal dari bahasa inggris yaitu mass yang berarti kelompok atau kumpulan. Dengan demikian media masa adalah perantara atau alat-alat yang digunakan oleh massa dalam hubunganya satu dengan yang lain. Media massa juga diartikan sebagai sarana komunikasi massa di mana proses penyamaian pesan, gagasan atau informasi disampaikan kepada orang banyak secara serentak. Penyampaian pesan ini dapat melaui surat kabar, radio, televisi dan film bioskop maupun lainnya (Fadilla, 2018: 7).

Media massa juga diartikan sebagai segala bentuk media atau sarana komunikasi untuk menyalurkan dan mempublikasikan berita kepada publik atau masyarakat. Bentuk media atau sarana jurnalistik ini terdiri dari media cetak, media elektronik, dan media online. Dari hal ini dapat disimpulkan bahwa media massa merupakan salah satu elemen penting dalam proses komunikasi massa sebagai salah satu sarana untuk memenuhi kebutuhan manusia akan informasi maupun hiburan, karena ia merupakan hasil produk teknologi modern sebagai saluran dalam komunikasi massa (Pengertian media massa pdf, dalam www.academia.edu.ac.id: 12).

Media massa ini mempunyai beberapa karakteristik dalam menyampaikan pesan. Pesan tersebut dapat berupa pesan berita secara langsung ataupun melalui pertunjukan film, sinetron, dan lainnya. Salah satu karakteristik media massa sebagai alat komunikasi massa adalah kecepatan penyampaian (kecepatan informasi yang tersebar lebih tinggi dari proses penyebaran dan kelangsungan tanggapan), dan keserempakan kontak (keseragaman dalam seleksi dan interpretasi pesan-pesan) dengan sejumlah besar penduduk dalam jarak yang jauh dari komunikator, sedangkan penduduk tersebut satu sama lainnya berada dalam keadaan terpisah (Efendi, 2000: 82). Karakteristik media massa lainnya adalah mampu memengaruhi dan mengubah opini publik. Oleh karenanya ia mempunyai dampak/ pengaruh baik positif maupun negatif.

Pengaruh positif media massa ialah masyarakat dapat menerima siaran berita dan informasi, dapat menambah wawasan pengentahuan, unsur hiburan yang dibutuhkan masyarakat dapat terpenuhi melalui siaran televisi, maupun berita di koran ataupun majalah (Mukaffi, dalam Japarudin 2012: 3). Sedangkan pengaruh negatif dari media massa dapat berupa pengurangan budaya dan moral serta sifat dari media massa itu sendiri. Media massa memiliki tanggungjawab moral dalam menyampaikan pesan kepada masyarakat 
Citra Perempuan Dalam Iklan...hal. 26-45

yang terealisasi dalam bentuk siaran progam-progam. Pemilihan penyiaran progam-progam yang tidak benar akan mempunyai dampak yang tidak baik pada masyarakat. Oleh karenanya, media massa diharuskan untuk tidak mencari keuntungan semata. Akan tetapi harus memperhatikan kode etik dan tata aturan yang berlaku karena informasi yang disampaikan oleh media masaa akan diterima masyarakat secara serentak (Holilah, 2016: 112).

Media massa pada umumnya merefleksikan sebuah realitas yang mencerminkan kenyataan atau lebih tepatnya merupakan representasi realitas sosial, di mana media massa diolah sedemikian rupa lalu dikemas dengan cara yang menarik sehingga menjadi sebuah realitas media yang memiliki ideologi tertentu, seperti patriakhi dan stereotip, karena melihat dari pengaruh media massa yang dapat mengubah perilaku masyarakat melalui penyampaian pesan yang disampaikan kepada masyarakat (Iriantara, t.t: 6). Dengan memanfaatkan peranan media massa pada semua lapisan masyarakat secara cepat, tepat, akurat dan sesuai kode etik, diharapkan penyampaian pesan yang difasilitasi oleh media massa dapat berhasil dengan baik (Japarudin, 2012: 3).

Secara umum media massa ini memiliki fungsi menyiarkan informasi, mendidik, dan menghibur. Untuk memainkan fungsinya media massa memiliki strategi komunikasi pendekatan dalam menyusun pesan-pesan yang akan disampaikan kepada khalayak (Muhtadi, 1999: 82).

\section{Perbedaan Peran dalam Konsep Sex dan Gender dalam Iklan ABC}

\begin{tabular}{|c|c|}
\hline Jenis Kelamin ( & Gender/ bukan kodrati \\
\hline $\begin{array}{l}\text { Menyangkut perbedaan organ biologis laki- } \\
\text { laki dan perempuan khususnya pada bagian } \\
\text { alat-alat reproduksi. Sebagai konsekuensi } \\
\text { dari fungsi alat-alat reproduksi, maka } \\
\text { perempuan mempunyai fungsi reproduksi } \\
\text { seperti menstruasi, hamil, melahirkan dan } \\
\text { menyusui; sedangkan laki-laki mempunyai } \\
\text { fungsi membuahi (spermatozoid) }\end{array}$ & $\begin{array}{l}\text { Menyangkut perbedaan peran, fungsi, dan } \\
\text { tanggungjawab laki-laki dan perempuan } \\
\text { sebagai hasil kesepakatan bersama dengan } \\
\text { konsequensi pembagian peran laki-laki } \\
\text { adalah mencari nafkah dan bekerja disektor } \\
\text { publik, sedangkan peran perempuan di } \\
\text { sektor domestik dan bertanggungjawab } \\
\text { untuk masalah rumah tangga. Karena sifat } \\
\text { dari gender ini bukan kodrati, maka peran } \\
\text { bisa berganti sesuai dengan kesepakatan } \\
\text { bersama. }\end{array}$ \\
\hline $\begin{array}{l}\text { Peran reproduksi tidak dapat berubah; sekali } \\
\text { menjadi perempuan dan mempunyai rahim, } \\
\text { maka selamanya akan menjadi perempuan; } \\
\text { sebaliknya sekali menjadi laki-laki, } \\
\text { mempunyai penis, maka selamanya menjadi } \\
\text { laki-laki. }\end{array}$ & $\begin{array}{l}\text { Peran sosial bisa berubah. Seperti peran istri } \\
\text { sebagai ibu rumah tangga dapat berubah } \\
\text { menjadi pekerja atau pencari nafkah, di } \\
\text { samping itu bisa tetap menjadi istri hanya } \\
\text { saja peran sosialnya yang berubah. }\end{array}$ \\
\hline
\end{tabular}


Yuli Susiyanah

Menyusui anak/bayi dengan payudaranya bagi Perempuan.
Mengasuh anak kandung, memandikan, mendidik, menyusui anak bayi dengan menggunakan botol bagi laki-laki atau perempuan.
Bagan tabel di atas menunjukkan bahwa peran sosial bukan bersifat kodrati. Artinya ia dapat berubah dan bisa dilakukan keduanya baik laki-laki atau perempuan (Puspitawati, 2013: 3). Bila diimplementasikan pada iklan kecap sedap $\mathrm{ABC}$, peran memasak yang awalnya hanya dilakukan oleh seorang istri atau ibu rumah tangga juga dapat digantikan oleh laki-laki atau suami. Hal ini ditunjukkan dengan suami yang membantu istrinya memasak (Https://youtu.be/nnv9fYekzOY).

\section{Ketidak-adilan Gender dalam Citra Perempuan di Media Massa}

Citra, dalam Kamus Besar Bahasa Indonesia, diartikan sebagai kesan mental atau bayangan visual yang ditimbulkan oleh sebuah kata, frasa, atau kalimat dan merupakan unsur dasar yang khas dalam prosa dan puisi (Ali, 1999: 192). Sedangkan dalam kamus istilah sastra Indonesia, citra disebut sebagai imaji, yaitu kesan batin atau gambaran visual yang timbul pada diri seseorang, yang disebabkan oleh suatu kata atau ungkapan dalam sebuah karya sastra (Rommy S, 2009: 22). Citra juga dapat mengarah kepada bentuk fisik, dan nonfisik sesuatu yang diacu, dan yang berkaitan dengan pengindraan, dan proses mental manusia. Hal ini sejalan dengan pendapat Wellek dan Warren yang menyatakan bahwa citra bersifat visual, yang merupakan suatu proses pengindraan atau presepsi, tetapi juga "mewakili" atau mengacu pada suatu yang tidak tampak, sesuatu yang berada di dalam.

Berdasarkan pendapat di atas dapat disimpulkan bahwa citra adalah gambaran atau cerminan mengenai suatu hal atau objek tertentu yang diperoleh dari hasil pengindraan atau kesadaran seseorang, baik bersifat visual maupun bersifat nonvisual. Dengan demikian dapat dinyatakan pula bahwa citra berkaitan erat dengan proses mental, dan proses fisik yang ada pada manusia sebagai pemberi makna dari citra itu (Wijiranto, 2014: 35).

Citra ini juga tidak lepas dari adanya peran media yang memengaruhi, yang mana hal itu berkaitan erat dengan pencitraan. Pencitraan merupakan penggambaran, cerminan yang dimiliki orang mengenai pribadi, kesan mental atau bayangan visual yang ditimbulkan oleh sebuah kata, frasa atau kalimat dari seseorang baik itu laki-laki maupun perempuan (Kasmiati, dkk, t.t: 5). Salah satu adanya pengaruh pencitraan adalah terbentuknya berbagai pandangan mengenai wanita dan laki-laki yang berkembang di media atau lebih mudahnya dikenal dengan istilah citra wanita dan lakilaki.

Citra wanita dibedakan menjadi dua yaitu citra diri wanita dan citra sosial wanita. Citra diri wanita merupakan keadaan dan pandangan wanita yang berasal dari dalam dirinya sendiri, yang meliputi aspek fisik dan psikis (Sugihastuti, 
2000: 112-113). Secara fisik, wanita dewasa merupakan sosok individu hasil bentukan proses biologis dari bayi perempuan, yang dalam perjalanan usianya mencapai taraf dewasa sehingga mempunyai hal-hal yang khas seperti dapat hamil, melahirkan, dan menyusui. Realitas ini menimbulkan mitos tentang wanita sebagai mother nature. Artinya mereka sebagai mahluk yang dapat menciptakan mahluk baru (melahirkan anak).

Selain fisik, citra perempuan secara psikis tidak terlepas dari feminitas. Prinsip feminitas ini ialah kecenderungan yang ada dalam diri wanita yang meliputi cinta kasih, mengasuh berbagai potensi hidup, orientasinya komunal dan memelihara hubungan interpersonal. Citra diri wanita tidak bisa lepas dari aspek psikis dan fisik. Adanya perbedaan bentuk fisik antara lakilaki dan perempuan memengaruhi pola pikir dan pola kehidupan wanita.

Sementara itu di sisi lain, citra perempuan juga melingkupi citra sosial wanita. Citra sosial wanita erat kaitannya dengan norma dan sistem nilai yang berlaku pada suatu kelompok masyarakat maupun kelompok keluarga. Dalam keluarga misalnya, wanita berperan sebagai istri, ibu, dan sebagai anggota keluarga yang masing-masing peran mendatangkan konsekuensi sikap sosial yang saling berkaitan (Sugihastuti, 2000: 143-144). Oleh karena itu citra sosial perempuan disebut sebagai citra wanita yang tidak lepas dalam keluarga dan citra dalam masyarakat yang berperan dalam masyarakat sebagai mahluk sosial (Sugihaastuti, 2000: 132). Citra inilah yang melahirkan kultur patriakhi. Perbedaan biologis antara laki-laki dan perempuan dianggap sebagai awal pembentukan budaya patriarkhi. Kultur patriarkhi yang membentuk perbedaan perilaku, status dan otoritas di masyarakat kemudian menjadi hirarki gender. Misalnya perempuan tidak memiliki otot dipercayai sebagai alasan masyarakat meletakkan perempuan pada posisi lemah. Sedang laki-laki karena memiliki otot dan memiliki fisik kuat maka diletakkan lebih tinggi dari perempuan.

Hal ini diungkap oleh Walby yang mengatakan bahwa partiarkhi merupakan sistem terstruktur dan praktek sosial yang menempatkan kaum laki-laki sebagai pihak yang mendominasi, melakukan operasi dan mengeksploitasi kaum perempuan. Sistem ini ada dalam dua bentuk yakni pertama private patriarkhi (partiarkhi domestic, yakni yang menekankan kerja dalam rumah tangga sebagai steorotipe perempuan) dan public patriakhi (patriarkhi public, yakni yang mensteorotipkan laki-laki sebagai pekerja di sektor publik yang sarat dengan karakter keras penuh tantangan). Kuatnya cengkeraman patriarkhi ini menyebabkan perempuan lebih banyak berada pada posisi marginal dan subordinat, karena posisi ini dibentuk oleh ideologi patriarkhi yang meneguhkan perempuan sebagai mahluk lemah. Pendapat tersebut telah menjadi ideologi umum yang tidak hanya memengaruhi masyarakat awam tetapi juga menjadi cara pandang negara dalam melihat dan menempatkan perempuan (Fujiati, 2016: 42-43).

Dalam penelitian yang dilakukan oleh Anthonia Paula Hutri Mbulu (2017: x) tentang citra perempuan dalam novel Suti Karya Sapardi Djoko Damono Kajian Kritik sastra Feminisme diungkapkan bahwa novel suti bersifat patriakhi artinya novel ini masih mempertahankan stereotif antara perempuan dan laki-laki secara

\section{Islamic Communication Journal Volume 4, Nomor 1, Januari-Juni 2019


patriakhi. Hal ini ditujukan adanya citra perempuan yang terbagi dalam citra diri perempuan (dilihat dari aspek fisik serta psikis) dan citra sosial dalam lingkungan keluarga serta masyarakat. Citra diri perempuan sesosok suti dalam novel ini menerangkan bahwa suti merupakan sosok perempuan yang bisa hamil, melahirkan, dan merawat anak. Dalam novel ini juga lebih lanjut dijelaskan mengenai aspek psikis perempuan yang dibedakan dalam kelas atas dan kelas bawah. Perempuan kelas atas secara ekonomi bergantung pada suami meskipun mereka mempunyai pengaruh di masyarakat. Sementara kelas bawah digambarkan memiliki kemandirian secara ekonomi walau pekerjaannya hanya sebagai pembantu rumah tangga.

Hal di atas menandakan, stereotif antara laki-laki dan perempuan disebabkan patriakhi yang melekat yaitu sebuah sistem di mana laki-laki mendominasi, melakukan opsesi dan melakukan eksploitasi atas perempuan (Fujiati, 2016: 43).

Adapun dalam penelitian Nursalim (t.t: 8) mengenai diskriminasi gender di media ma dijelaskan bahwa perempuan dalam media selalu menjadi pemanis, pelembut, bahkan perempuan menjadi daya tarik tersendiri mengisi acara-acara atau siaransiaran di media. Daya tarik yang dimaksud kadang-kadang melecehkan perempuan sendiri karena kecantikanya untuk ditonton dan dinikmati oleh semua orang, perempuan juga digambarkan sebagai makhluk yang lemah yang harus dilindungi, disayangi. Sedangkan laki-laki digambarkan sebagai makhluk yang kuat, energik, pelindung, dan tidak terkuasai oleh perempuan.

Dari penggambaran di atas nampak bahwa perempuan masih diidentikan sebagai makhluk yang belum sepenuhnya berdiri sendiri, tetapi masih membutuhkan laki-laki untuk melindungi diri. Pandangan ini akan melekat dalam masyarakat selagi media belum merekontruksi pandangan mengenai perempuan dalam media.

Ketiga penelitian Aprilian Hening Puspitasari (2017: 248-249) yang berjudul "Menggugat Stereotif Perempuan Sempurna" Framing Media terhadap Perempuan Pelaku Tindak Kekerasan. Hasil penelitian menunjukkan bahwa stigma dan peran domestik masih kental dilekatkan dalam mengukur kesempurnaan perempuan. Dengan kekuatan mengkonstruksi realitas dan membentuk opini publik, media belum sepenuhnya menghadirkan prinsip-prinsip jurnalisme empati. Pedoman pemberitaan dan penguatan jaminan negara terhadap penghapusan diskriminasi perempuan di media menjadi alternatif solusi untuk meningkatkan peran media agar isu-isu kesetaraan gender dapat dipahami masyarakat. Dalam penelitian ini nampak problem utama terkait perempuan ialah diskriminasi terhadap perempuan dalam peran domestik perempuan.

Berdasarkan pemaparan-pemaparan di atas nampak bahwa citra perempuan dalam media masa masih menggunakan stereotif yang melekat pada perempuan. Bahkan budaya patriakhi masih digunakan media dalam menggambarkan citra perempuan. Perempuan selain sebagai sosok yang dikenal lemah lembut, dalam media masa masih banyak yang mencitrakan perempuan dengan budaya patriakhi dan stereotif yang melekat pada dirinya tidak terkecuali terkait peran domestik perempuan. 
Peranan Media Massa dalam Mewujudkan Kesetaraan Gender

Media massa mempunyai peranan yang sangat penting dalam membentuk opini publik. Sebagaimana diketahui bahwa media massa sangat berperan dalam perkembangan dan perubahan pola tingkah laku dari suatu masyarakat. Hal ini disebabkan media masa mempunyai jaringan yang sangat luas dan bersifat masal sehingga pengaruh media masa akan terlihat di permukaan masyarakat luas (Setiawan, dalam http://ejournal.undip .ac.id). Sebagai contoh media massa yang menyajikan berbagai hal dengan mengatasnamakan kebebasan media dengan memberi porsi lebih besar pada pria sebagai subjek dibandingkan dengan perempuan menjadi salah satu bentuk "kesemena-menaan" gender sehingga akan memengaruhi opini publik mengenai persepsi perempuan dan laki-laki (Iriantara, dalam https://www.academia.edu).

Selain itu, media massa juga berisi penyampaian informasi atau hiburan kepada masyarakat. Penyampaian hiburan atau informasi ini biasanya diambil dari realitas kehidupan masyarakat sehari-hari yang dikemas dan disosialisasikan dalam bentuk hiburan walau sifat hiburan ini hampir semuanya bersifat fiktif. Inilah peran media yang disebut sebagai agen utama sosialisme yang bertujuan untuk menyosialisasikan nilai-nilai tertentu (Nursalim, t.t: 8) tak terkecuali nilai-nilai dalam mewujudkan kesetaraan gender.

Menurut MC Quail dalam bukunya Mass Comunication Theories, ada enam peran media masa dalam kehidupan sosial yaitu:
Pertama, media massa sebagai window on event and experience. Artinya media dipandang sebagai jendela yang memungkinkan khalayak melihat apa yang sedang terjadi di luar sana untuk mengetahui berbagai peristiwa.

Kedua, media juga sering dianggap sebagai a mirror of event in society and world, implying a faithful reflection. Artinya cermin berbagai peristiwa yang ada di masyarakat dan dunia yang merefleksikan apa adanya. Oleh karenanya para pengelola media sering merasa tidak bersalah jika isi media penuh kekerasan, konflik, pornografi dan berbagai ketidakadilan, karena memang menurut mereka faktanya demikian. Media hanya sebagai refleksi fakta, terlepas suka atau tidak suka. Padahal sesungguhnya arah dan framing dari isi yang dianggap sebagai cermin realtias tersebut diputuskan oleh para profesional media sehingga media tidak sepenuhnya bebas dalam menyampaikan sebuah informasi.

Ketiga, memandang media massa sebagai filter, atau gatekeeper yang menyeleksi berbagai hal untuk diberi perhatian atau tidak. Media senantiasa memilih isu, informasi atau bentuk content berdasar standar para pengelolanya. Di sini khalayak dipilihkan oleh media tentang apa-apa yang layak diketahui dan mendapat perhatian.

Keempat, media massa sering kali dipandang sebagai guide, petunjuk jalan atau interpreter, yang menerjemahkan dan menujukkan arah atas berbagai ketidakpastian, atau alternatif yang beragam.

Kelima, media masa sebagai forum untuk mempresentasikan berbagai informasi dan ide-ide kepada halayak 
Yuli Susiyanah

sehingga memungkinkan terjadinya tanggapan dan umpan balik.

Keenam, media massa sebagai interlocutor, yang tidak hanya sekedar tempat berlalu lalang informasi, dan ide-ide kepada khalayak, tetapi juga patner komunikasi yang memungkinkan terjadinya komunikasi interaktif (McQuail, 2000: 66).

Dari hal di atas, pada umumnya peran media dalam kehidupan sosial bukan sekedar sarana diversion, pelepas ketegangan atau hiburan tetapi isi dan informasi yang disajikan mempunyai peran yang signifikan dalam proses sosial. Isi media merupakan konsumsi otak bagi khalayaknya sehingga apa yang ada di media masa akan memengaruhi realitas subjektif pelaku interaksi sosial. Gambaran realitas yang dibentuk oleh media masa inilah yang nantinya mendasari respon dan sikap khalayak terhadap berbagai objek sosial. Informasi yang salah akan memunculkan gambaran di benak masyarakat yang salah pula. Untuk itulah media massa ditunrut menyuguhkan informasi yang berkualittas dan akurat, karena kualitas informasi ini merupakan tuntunan etis dan moral penyajian media masa (Aditya, dalam http:// ejournal.undip.ac.id).

Dari pemaparan di atas, nampak bahwa media massa mempunyai peranan yang sangat besar terhadap wacana publik. Apa yang disampaikan media kepada khalayak, khlayak akan menerima informasi itu sebagai landasan masyarakat berfikir mengenai infomsai yang mereka terima. Informasi yang tidak tepat akan memengaruhi pola pikir masyarakat mengenai suatu informasi dan dari hal ini akan mempunyai dampak dan pengaruh yang sangat besar terhadap wacana publik.
Oleh karenanya, media massa pula dikatakan mempunyai pengaruh yang sangat besar terhadap wacana publik.

\section{Temuan Hasil Penelitian: Citra perempuan dalam Iklan Kecap ABC Suami Sejati Mau Masak sebagai Implementasi Konsep Gender Relatinship dan Kesetaraan Gender}

Iklan pada umumnya mencerminkan realitas yang merefleksikan kehidupan manusia sehari-hari. Adapun analisis iklan dalam studi ini dibedakan berdasarkan visualisasi (penggambaran) dan verbalisasinya (audio, intonasi, sound effect) mengingat dalam studi ini iklan yang dianalisis adalah iklan televisi yang menggunakan medium audio visual. Iklan menggambarkan citra dan peran melalui bahasa yang digunakan. Untuk mengetahui citra perempuan pada iklan kecap $\mathrm{ABC}$, maka dapat dianalisis menggunakan teks verbal yang terkandung dalam iklan ini. Adapun teks verbal dalam iklan ini yaitu:

Ayah : Haah.. Capeknya! Itu adek yah?

Anak : Ini Super Bunda

Ayah : Kekuatan Super Bunda apa?

Anak : Banyak. Bangun Pagi, Kerja, masak.

Ayah : Kalau Ayah?

Anak : Ayah Cuma ngantor. Bunda udah ngantor masih kuat masak. (sambil menunjuk bundanya yang sedang menyiapkan bahan-bahan untuk memasak). Ayah : (menengok istrinya dan berjalan kearah istri) Maaf yah gak pernah bantu. Harusnya, kalau kamu bisa kerja aku juga bisa masak. (sembari mengambil spatula yang sedang dipegang istrinya). 
Citra Perempuan Dalam Iklan...hal. 26-45

Bunda : Mau bantu? Ini bisa bantu. (sembari mengambil kecap ABC)

Narator : Kecap ABC dibuat dari perasan pertama kedelai pilihan. Bikin masakan lebih kaya rasa, lebih mudah, siapapun yang masak. Kecap ABC, Bantu suami sejati masak lebih baik.

Teks di atas merupakan naskah dialog yang terdapat pada iklan kecap ABC. Dalam dialog ini terdapat berbagai tuturan yang menunjukkan citra perempuan dalam iklan ini, yaitu:

a. Peran domestik

Dalam iklan kecap ABC dengan judul "Suami sejati mau masak" (Https:// youtu.be.com/ nnv9fYekzOY), citra perempuan pada umumnya digambarkan sebagai sosok perempuan super yang biasa bangun pagi, kerja dan masak. Artinya peran perempuan awalnya diidentikkan dengan peran domestik rumah tangga yang biasa mengurus kegiatan rumah. Walau mereka sudah bekerja, akan tetapi peran domestik perempuan sebagai ibu rumah tangga yang mempunyai kegiatan masakmemasak tidak dapat dilepaskan. Penjelasan ini dapat dilihat dari visual dan dialog percakapan antara ayah dan anak seperti di bawah ini:

Ayah : Haah.. Capeknya! Itu adek yah?

Anak : Ini Super Bunda

Ayah : Kekuatan Super Bunda apa?

Anak : Banyak. Bangun Pagi, Kerja, masak.

Ayah : Kalau Ayah?

nak : Ayah Cuma ngantor. Bunda udah ngantor masih kuat masak. (sambil menunjuk bundanya yang sedang menyiapkan bahan-bahan untuk memasak).

\section{Gambar 1}

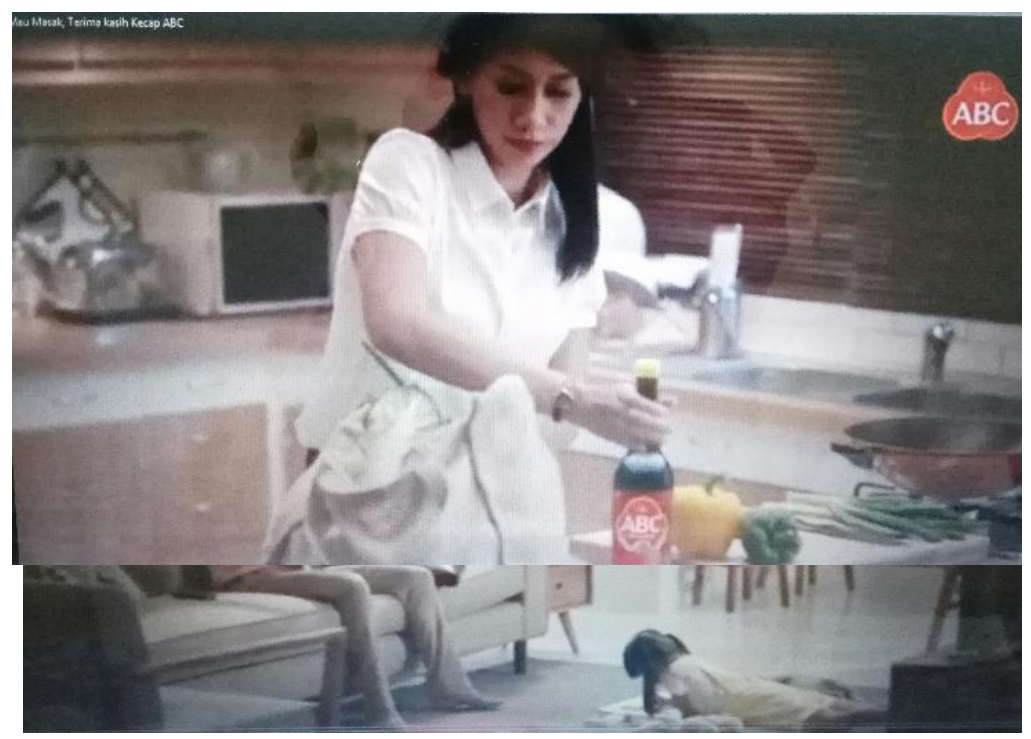

Gambar 2

Gambar di atas menunjukkan bahwa peran domestik selalu dilakukan oleh pihak perempuan sehingga seusai bekerja, perempuan tetap identik dengan pekerjaan rumah. Hal ini menunjukkan adanya adanya stereotip terkait perempuan bahwa 
Yuli Susiyanah

peran domestik selalu melekat pada peran perempuan karena ia tidak lepas dari bagian perempuan itu sendiri.

Stereotip peran domestik perempuan yang melekat secara umum pada masyarakat, dalam iklan ini ditunjukkan dengan gambar ke 2. Adapun suaminya selepas bekerja diidentikan dengan istirahat. Seorang suami yang pulang kerja b. Konsep kesetaraan gender hanya duduk di kursi sembari menanyakan anaknya yang sedang menggambar sesosok perempuan. Dari hal ini, nampak iklan ini memunculkan sebuah konsep stereotip yang melekat pada budaya perempuan yang sudah berkembang di masyarakat. Konsep itu ditunjukkan oleh adanya peran perempuan dan laki-laki yang tidak setara.

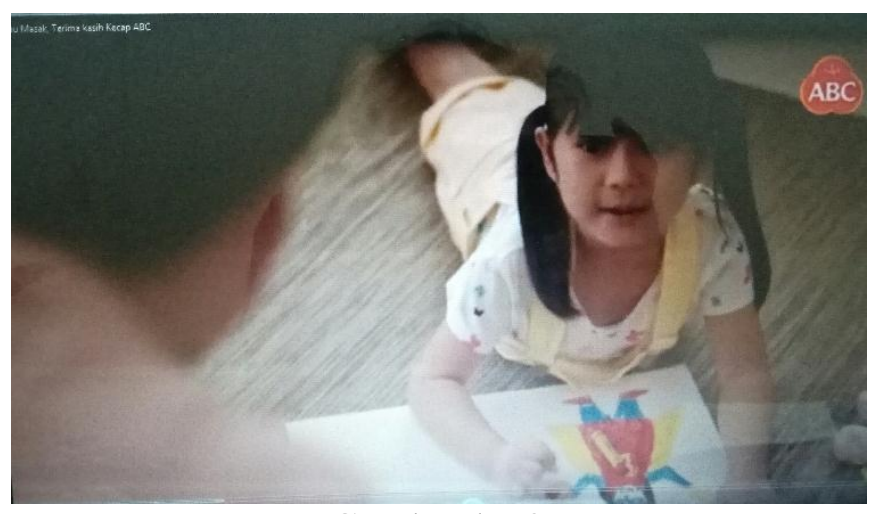

Gambar ke 3

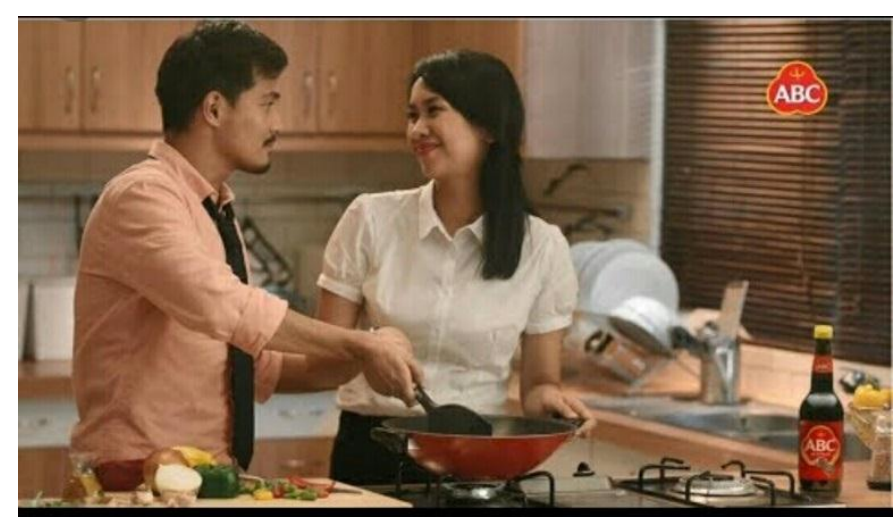

Gambar ke 4

Visualiasasi ke 3, menggambarkan hanya bekerja menurut anak tersebut. seorang anak yang menjelaskan bahwa Penjelasan seorang anak tentang peran sesosok perempuan yang digambarnya ayahnya yang hanya bekerja, sedangkan adalah super bunda (seorang ibu yang ibunya mampu bangun pagi, bekerja dan mempunyai kekuatan). Dengan rasa masih bisa memasak, sontak membuat hati penasaran, seorang ayah menanyakan seorang ayah ini tergerak kala melihat sang kekuatan super bunda, yang menurut anak istri. Kemudian iapun menghampiri istrinya tersebut mempunyai kekuatan bisa bangun yang sedang memasak dan meminta maaf pagi, kerja dan masak sementara ayahnya karena selama ini tidak pernah membantu 
memasak sembari mengatakan "harusnya kalo kamu bisa kerja, aku juga bisa masak."

Dari penggambaran di atas nampak terlihat adanya sebuah konsep baru yang di usung oleh iklan ini. Perempuan yang biasanya di stereotipkan dengan peran domestik seperti memasak ternyata dalam iklan ini, peran memasak dapat dilakukan oleh laki-laki/seorang suami. Artinya ada kesataraan peran yang diusung oleh iklan ini, yaitu konsep kesetaraan gender antara laki-laki dan perempuan. Jika perempuan bisa bekerja dan memasak maka laki-laki juga bisa melakukan hal demikian. Penjelasan ini ditunjukan oleh gambar ke 4.

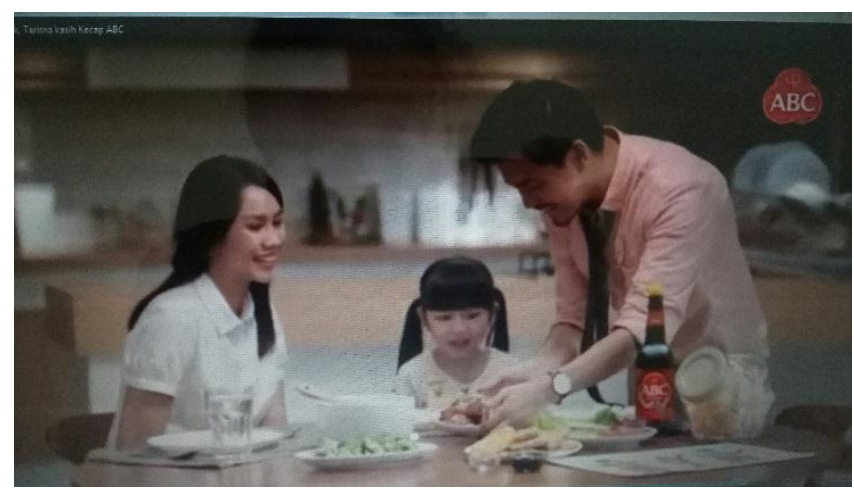

Gambar ke 5

Sementara itu, visualisasi akhir dalam iklan ini dideskripsikan dengan suami istri yang memasak bersama serta menyajikan masakannya di meja makan dan makan bersama. Pada saat menyajikan makanan di meja makan, nampak tersaji sebuah gambar keluarga yang terdiri dari seorang ayah, seorang ibu dan seorang anak. Gambar seorang ibu dideskripikan dengan tulisan "Super Bunda" yang sedang memegang laptop di tangan kanan dan spatula (alat memasak) di tangan kiri, sedangkan di sisi kanan terdapat gambar seorang ayah yang dideskripsikan dengan tulisan "super ayah" dengan tangan kiri memegang spatula. Kedua gambar tersebut dihubungkan dengan gambar seorang anak yang memegang tangan kedua orang tuannya ke atas (Https:// youtu.be/ nnv9fYekzOY).

Dari penjelasan di atas, tergambar bahwa konsep kesetaraan gender yang diusung oleh iklan ini tercapai sempurna. Hal ini ditunjukkan dengan adanya peran domestik yang tidak hanya dilakukan oleh perempuan akan tetapi dapat juga dilakukan oleh laki-laki yang disimbolkan dengan gambar seorang ayah/laki-laki yang memegang spatula. Artinya tidak ada yang membedakan antara peran laki-laki dan perempuan dari segi domestik. Baik lakilaki atau perempuan keduanya dapat melakukan bersama-sama demi tercapainya kerjasama dalam pembagian peran keluarga.

Berdasarkan pemaparan-pemaparan di atas dapat dikatakan bahwa iklan kecap $\mathrm{ABC}$ "suami sejati mau masak" dengan menggunakan teori gender relationship menunjukan bahwa peran domestik dapat dilakukan oleh perempuan maupun lakilak. Artinya dalam hal ini juga nampak media massa telah merekontruksi konsep ketidak-setaraan gender menuju setara dengan mendesain sedemikian iklan ini agar dapat memengaruhi halayak mengenai stereotip yang berkembang di masyarakat yakni peran domestik yang identik dengan tanggungjawab perempuan dengan laki-laki

\section{Islamic Communication Journal Volume 4, Nomor 1, Januari-Juni 2019


bisa melakukan peran domestik. Dengan pendekatan media massa, citra perempuan sebagai agen utama peran domestik dalam keluarga dapat terkontruksi dengan baik menjadi setaraan gender.

Media massa sebagai pendekatan, dapat memengaruhi opini publik berkenaan dengan citra perempuan yang di stereotipkan sebagai agen domestik dalam keluarga dan dapat merekontruksi citra baru tentang peran domestik yang melekat pada perempuan. Fungsi media sebagai penyampai informasi dapat memengaruhi pola pikir masyarakat karena apa yang disampaikan media kepada khalayak, khalayak akan menerima informasi itu sebagai landasan berfikir dalam menerima infomasi. Iklan yang ditampilkan dalam kecap $\mathrm{ABC}$ ini mempunyai makna bahwa peran domestik tidak hanya dilakukan oleh perempuan akan tetapi laki-laki juga dapat melakukan peran tersebut selagi peran tersebut bukan kodrati melainkan hasil kontruksi dari sosial atau kultural.

\section{PENUTUP}

Media massa mempunyai peranan yang sangat penting dalam kehidupan, dengan media massa dapat membentuk opini publik. Iklan kecap ABC dengan bantuan teori gender mampu merekontruksi stereotif yang selama ini berkembang di masyarakat. Stereotif tentang peran domestik yang biasanya dilakukan oleh perempuan atau diidentikan dengan tugas perempuan, dengan kehadiran iklan kecap $\mathrm{ABC}$ suami sejati mau masak, mampu mengubah citra perempuan dalam media massa. Peran domestik yang pada umumnya dilakukan oleh perempuan ternyata hal ini juga dapat dilakukan oleh laki-laki, artinya peran domestik dalam keluarga menjadi tugas bersama antara istri dan suami atau dapat dilakukan secara bersama tergantung keluarga mengatur dan mengolah demi terwujudnya keharmonisan bersama. Hal ini juga menunjukkan adanya kesetaraan peran yang diusung antara laki-laki dan perempuan. Jika laki-laki dapat bekerja dan perempuan dapat memasak maka tidak salah jika perempuan juga bisa kerja dan Laki-laki bisa memasak karena mereka mempunyai hak yang setara.

\section{DAFTAR PUSTAKA}

Alston, M. Gender Mainstreaming in Practice: A view from Rural Australia, NWSA Journal, 2006.

Astuti,Yanti Dwi, "Media dan Gender (Studi Deskriptif Representasi Stereotipe Perempuan dalam Iklan di Televisi Swasta" dalam Jurnal Komunikasi, Vol. 09, No. 02, Oktober 2016.

Aditya, Ariya,Peran Media Massa dalam Meningkatkan Kualitas Kepemerintahan Lokal Berbasis Human Scuirity di Kota Jaya Pura, Http://ejournal.undip.ac.id.

Amin, Nasihun, Relasi Gender dalam isuisu keagaman; Studi Terhadap Pandangan Organisasi Wanita Massa Islam Kota Semarang, (Semarang: Lembaga Penelitian IAIN Walisongo, 2012).

Bungin,Burhan,Sosiologi Komunikasi, (Jakarta: Kencana, 2011), dalam penelitian Nurdin Abd Halim, Media dan Pencitraan 
Citra Perempuan Dalam Iklan...hal. 26-45

Perempuan, (Riau: Universitas Mohammadiyah Riau, t.t).

Catatan Komnas Perempuan 2018 dalam Https://www.komnasperempuan.g o.id.

Ch., Mufidah,Rekonstruksi Kesetaraan dan Keadilan Gender dalam Konteks Sosial Budaya dan Agama, file PDF.

Efendi, Onong Uchyana,Ilmu Komunikasi Teori dan Praktek, (Bandung: Remaja Rosdakarya, 2000).

Fadilla,Nur, dalam eprints.umm.ac.id, diakses tanggal 22 Desember 2018, pukul 14.00.

Fujiati,Danik, "Seksualitas Perempuan dalam Budaya Patriarkhi”, dalam Jurnal Muwazah ISSN 2502-5368 (Paper) ISSN 2085-8353 (Online), Vol. 8, No.1, Juni 2016.

Halim,Nurdin Abd,Media dan Pencitraan Perempuan, (Riau: Universitas Mohammadiyah Riau, t.t)

Hatifah, Ratu Dian, Pengaruh Relasi Gender dan Pengambilan Keputusan Terhadap Kinerja Guru Sekolah Menengah Pertama Negeri (SMP Negeri) Di Kecamatan Bekasi Selatan Kota Bekasi, dalam http://www.medianeliti.com.

Hariyanto, Gender dalam Kontruksi Media, dalam Jurnal Komunika, Vol.3, No.2, Juli-Desember 2009.

Holilah, Ilah, Dampak Media Terhadap Perilaku Masyarakat, dalam Jurnal Studi Gender dan Anak, Vol 3, No.1, Januari-Juni, 2016.

Inpres No. 29Tahun 2000 tentang Pedoman Pengarusutamaan Gender dalam Pembangunan Nasional dalam Prof. Dr. Aida Vitayala S. Hubeis, gender Mainstreaming dan pendekatan efisiensi waita dalam pemangunan.

Iriantara,Yosal, Media, gender dan melek media, dalam Https://www.academiaedu.ac.id.

Japarudin, Media Massa dan Dakwah, dalam Jurnal Dakwah, Vol. XIII, No.1 Tahun 2012.

Kasmiati dkk, Citra Perempuan dalam Novel Habibie dan Ainun Karya Bachauddin Jusuf Habibie, (Riau: FKIP Uiveristas Pekanbaru, t.t).

Kadarusman, Agama, Relasi Gender, \& Feminisme, (Yogyakarta: Kreasi Wacana, 2005).

Komnas Perempuan, Tergerusnya Ruang Aman Perempuan dalam Pusaran Politik Populisme, dalam Catatan Kekerasan terhadap Perempuan tahun 2017, Jakarta, 7 Maret 2018, pdf.

Lukman Ali, Kamus Bahasa Indonesia, (Jakarta: Balai Pustaka, 1999).

Mukaffi,Abdurrahman,Kategori Acara TV dan Media Cetak Haram di Indonesia, (Jakarta: Darul falah, 2001), dalam Japarudin, Media Massa dan Dakwah, dalam Jurnal Dakwah, Vol. XIII, No.1 Tahun 2012.

Martiany,Diana, Implementasi Pengarusutamaan Gender (PUG) sebagai strategi Pencapaian Kesetaraan Gender; Studi Di Provinsi Sumatra Utara dan Jawa Tengah, dalam jurnal Aspirasi, Vol 2, No.2, Desember 2011.

Mbulu, Anthonia Paula Hutri, "Citra Perempuan dalam Novel Suti Karya Sapardi Djoko Damono: Kajian Kritik Sastra Feminisme, 
Yuli Susiyanah

(Yogyakarta: Universitas Sanata Dharma, 2017).

Mustika, "Diskriminasi terhadap Beberapa Perempuan dalam Persepektif Feminisme Multikultural: Kajian Terhadap Novel Scappa Per Amore Karya Dini Fitria" dalam Jurnal Poetika, Vol. IV, No. 1, Juli 2016.

Muhtadi,Asep

Saepul,Jurnalistik

Pendekatan Teori dan Praktek, (Jakarta: Logos Wacana Ilmu, 1999).

Muhajir, Noeng, Metode Peneletian Kualitatif, (Yogyakarta: Rake Sarasih, 1996).

McQuail,Denis Mass Comunication Theories, Fourth edition, (London: Sage Publication, 2000), 66, dalam Ariya Aditya, Peran Media Massa dalam Meningkatkan Kualitas Kepemerintahan Lokal Berbasis Human Scuirity di Kota Jaya Pura, http://ejournal.undip.ac.id.

Nahayi,Manggala, "Objektifikasi perempuan oleh Media:

Pembakuan Identitas Perempuan dan Kekuasaan laki-laki”, dalam www.academia.edu.ac.id.

Ni'matusyifa, Analisis Peran Pusat Studi Gender dan Anak (PSGA) IAIN Walisongo dalam Mewujudkan Kesetaraan Gender, (Semarang: Lembaga Penelitian IAIN Walisongo, 2014).

Nursalim, Diskriminasi Gender Di Media Televisi, (Riau: UIN Suska, t.t).

Purwaningsih,Sri,Kiai dan Keadilan Gender, (Semarang: Walisongo Press, 2009).

Puspitasari,Aprilia Hening, "menggugat Stereotip Perempuan sempurna $44 \quad \begin{aligned} & \text { Islamic Communication Journal } \\ & \text { Volume 4, Nomor 1, Januari-Juni } 2019\end{aligned}$
Framing Media terhadap Pelaku Tindak Kekerasan", Vol. 10, No. 2, Desember 2017.

Puspitawati, Herien, Konsep, Teori dan Analisis Gender, (Bogor: PT IPB Press, 2012).

Ramli, Mohd Anuar, Analisis Gender dalam Hukum Islam, dalam Jurnal Fiqh, No.9, 2012.

Rintri Ani Pardede, Manifestasi Citra Perempun dalam Iklan; Analisis semiotika pierce Iklan molto periode 2013-2015, (Yogyakarta: uin Sunan kalijaga, 2016).

Rahayu,Wewen Kusuma, Analisis Pengarusatamaan Gender Dalam Kebiakan Publik; Studi Kasus Di BP3AKB Provinsi Jawa Tengah, dalam Jurnal JAKPP, Vol 2, No.1, Juni 2016.

Rommy S,Fatimah citra laki-laki dalam tiga cerpen Abdurrahim Nashar, (Depok: UI, 2009).

Setiawan, Aria Aditya, Peran Media Massa dalam Meningkatkan Kualitas Kepemerintahan Lokal Berbasis Human Scuirity di Kota Jaya Pura, dalam http://ejournal.undip.ac.id

Siscawati,Mia,Panduan Pengarusatamaan Gender dalam Siklus Pengelolaan Progam, dalam Forest Governance Progam Phase 2 (FGP2) Kemitraan, Bogor, Februari 2015.

Sugihastuti, wanita dimata wanita; perspektif sajak-sajak toery heraty (t.t: Nuansa, 2000).

Wijiratno,Eko Bambang,Potret Perempuan dalam Novel Dunia Patmini Karya Trie Utami; analisis feminisme, (Tuban: Universitas PGRI Ronggolawe, 2014). 
Citra Perempuan Dalam Iklan...hal. 26-45

Wojowasito, Prof. S. dan Drs. Tito Wasito

W, Kamus Lengkap Inggris-

Indonesia Indonesia-Inggris,

(Bandung: Angkasa Offset, 1980).

Https://youtu.be/nnv9fYekzOY, diakses

pada tanggal 22 Desember 2018. 